NOTICE: this is the author's version of a work that was accepted for publication in International Review of Economics and Finance. Changes resulting from the publishing process, such as peer review, editing, corrections, structural formatting, and other quality control mechanisms may not be reflected in this document. Changes may have been made to this work since it was submitted for publication. A definitive version was subsequently published in International Review of Economics and Finance, Vol. 29 (2014). DOI: 10.1016/j.iref.2013.04.004 


\section{Can gold prices forecast the Australian dollar movements?}

\section{Nicholas Apergis}

Department of Banking \& Financial Management, University of Piraeus, Greece

Department of Banking \& Financial Management, University of Piraeus, 80 Karaoli \& Dimitriou, 18534 Piraeus, Greece, Tel. +30-210-4142429, E-mail: napergis@unipi.gr 


\section{ABSTRACT}

This paper explores whether gold prices have a reliable out-of-sample relationship with the Australian dollar/US dollar nominal and real exchange rate using daily and quarterly data, respectively, spanning the period 2000-2012. Through an Error Correction Model (ECM), the empirical findings suggest that the out-of-sample predictive ability is strong and robust across short- and long-run horizons. The results could offer informational availability for monetary policymakers, hedge funds managers and international portfolio managers. They also provide additional support to the hypothesis that both markets are driven by the same information sets.

\section{JEL Classification:}

\section{F31}

F37

Q11

$\mathrm{C} 22$

Keywords:

Gold prices

Australian dollar/US dollar exchange rate

Error correction model

Predictive ability

\section{Introduction and literature}

The breakdown of the Bretton Woods System on August 15, 1971 and the adoption of the regime of the freely floating exchange rates generated an increasing interest in the examination of the relationship between currency exchange rates movements and economic parameters such as supply, demand, interest rates, economic growth, inflation rates and other macroeconomic fundamentals (Sercu and Uppal, 1995). The relationship between economic parameters and exchange rates has been one of the most controversial issues in international economics and a longstanding puzzle. 
On the first hand, Meese and Rogoff (1983) are the first who show that it is virtually impossible to explain or predict nominal exchange rates using standard macroeconomic models and fundamental variables to short term periods, though they find that accuracy generally increases at longer periods and demonstrate that a variety of linear structural exchange rate models fail to forecast more accurately than a naive random walk model. Frankel and Rose (1995) conclude with doubts about the value of further time series modeling of exchange rates at high or medium frequencies using macroeconomic models and summarize the various difficulties in empirically relating exchange rate behavior to shocks in macroeconomic fundamentals. Moreover, empirical evidence in favor of predictive ability of macroeconomic fundamentals has been mainly found at longer horizons (Engel et al., 2007). Cheung et al. (2005) conclude that models with macroeconomic fundamentals cannot outperform the random walk and only models with Taylor rule fundamentals can have some predictive merit (Molodtsova and Papell, 2009; Wang and Wu, 2012).

The primary goal of this empirical paper is to examine, for the first time, the predictive ability of gold prices for the nominal/real exchange rate of the Australian dollar (with respect to the US dollar). The fluctuations of gold prices are crucial for the value of the AU dollar. This is because once foreign exchange traders know whether this commodity is strongly correlated with the production and exports potential characteristics, they can better predict how gold prices could affect the exchange rate. Our empirical findings suggest that we find a strong systematic relation between gold prices and the exchange rate. In other words, we conjecture that the mechanism leading to these results is the fact that, for an open economy exporting gold, the exchange rate should reflect fluctuations in gold prices (Obstfeld and Rogoff, 1996). Our empirical work is closely related to the literature on using commodity prices to predict exchange rates. Chen et al. (2010) provide evidence in favor of the fact that the out-of-sample predictive ability of commodity prices for nominal exchange rates is minimal, while Chen and Rogoff (2003) consider commodity price indices and find in-sample empirical evidence for predicting real exchange rates. Beckmann and Czudaj (2013) investigate the association between oil and effective dollar prices through a nonlinear adjustment model and they document causality runs from exchange rates to oil prices and not vice versa. In terms of volatility transmissions, Hammoudeh et al. (2010) show how the conditional volatility 
of a number of precious metals, including gold, affects the volatility of the US dollar/Euro exchange rate, with their results documenting that there exist interdependencies between the volatility coming from the previous metals price and the relevant exchange rate. Finally, Ewing and Malik (2013) also find strong evidence of a strong volatility transmission mechanism between gold and oil futures prices, supporting cross-market hedging strategies and sharing common information sets across markets.

For Canada, Australia and New Zealand, countries that depend heavily on their commodity exports, the world price of commodities appears to have a strong and systematic relationship to their currencies (Chen and Rogoff, 2003). Chen (2004) extends his work to look at commodity-price augmented monetary models for nominal exchange rate determination and out-of-sample forecasts. He finds that the inclusion of a commodity price term can improve the forecast performance of these standard models dramatically. It has long been observed that there is a close relationship between the price of some primary commodities such as gold, oil, agricultural products and certain currencies, described as 'commodity currencies', with a large share of production and exports accounted by primary commodity products as the ones described before. The main idea behind 'commodity currencies' is that the value of a commodity currency usually rises and falls in relation with the value of the country's main commodity exports. Both the value of a commodity and the country's trade balance, with respect to the commodity, are significant factors in the valuation of commodity currencies. The most commonly traded 'commodity currencies' are those of the Canadian dollar, the New Zealand dollar and the Australian dollar. These three countries are highly integrated into global capital markets and are active participants in international trade.

Since 1983 the Australian dollar (AUD) has been floated, while core reforms, i.e. the development of an active local bond market and a non-deliverable forward currency market, led to the 'internationalization' of the currency and to a substantial rising of the living standards of Australians. This regime allowed the economy to absorb such shocks without the inflation changes that characterized the previous managed floating regime. Today the AUD is the sixth most traded currency globally, while the exchange rate between the AUD and the USD is the fourth most traded currency pair. 
Commodity terms of trade have recently attracted renewed interest due to their wild fluctuations. Indeed, commodity prices are generally found to drive exchange rate fluctuations in commodity-exporting countries (Chen and Rogoff, 2003; Cashin et al., 2004) and econometric models of equilibrium exchange rates often include this series among their explanatory variables (Isard, 2007; Ricci et al., 2008). It has been also contended that movements in Australia's exchange rate are influenced substantially by changes in its terms of trade. This view has been corroborated by the work of Blundell-Wignall and Gregory (1990) and Gruen and Wilkinson (1994) who establish a long-run relationship between Australia's exchange rate and its terms of trade. This should be of interest to all those countries whose currencies seem to be susceptible to terms-of-trade shocks. The list of such countries includes not only small, open, commodity-exporting countries like Australia, Canada, and New Zealand whose terms of trade are shocked positively by rises in international commodity prices, but also the USA, Japan, and Germany whose terms of trade are shocked negatively by rises in international oil prices.

Australia is a major exporter of mining and agricultural commodities and it has long been observed that there is a close relationship between commodity prices and the AUD (Viney, 2000). According to Viney (2000), commodity prices, at least in the medium-term, affect the value of the AUD due to Australia's dependence on mining and farming exports. When the world price of commodities rises, the AUD tends to appreciate and vice versa. Blundell-Wignall and Gregory (1990), BlundellWignall et al. (1993) and Gruen and Wilkinson (1994) argue that the terms of trade are a fundamental determinant of the real exchange rate for a commodity exporting country like Australia, following the long literature that has studied the impact of exchange rate volatility and exchange rate regimes on trade flows (McKenzie, 1999). Sercu and Uppal (1999) conclude that even in a very simple model it is possible to have either a negative or a positive relation between trade and exchange rate volatility, depending on the source underlying the increase in exchange rate volatility. Moreover, Chen et al. (2010) support that price fluctuations in world commodity markets represent exogenous terms-of-trade shocks that impact a significant share of their country' exports.

After coal, iron ore, and crude petroleum, gold currently ranks fourth in value of all Australia's merchandise exports. There is perhaps no other industrial endeavor 
that has had such a profound effect on the Australian nation as gold economically and socially. Australia has had a productive and vibrant gold industry for over 150 years, while the extent of economic gold resources has always been a difficult issue to quantify; therefore, the fluctuations of international prices of gold are extremely crucial for the value of the AUD.

The increase in world gold prices to more than USD500 an ounce by the early 1980 s and the widespread acceptance of exploration techniques, led to a rapid increase in gold production. It is true that gold in many cases characterized and as 'safe haven' for investors seeking protection from falling stock prices (Baur and Lucey, 2007). In other words, the presence of gold is likely to enhance the stability and resiliency of the financial system, because it dampens negative shocks falling on various assets through the gains obtained by gold that functions as a 'safe haven' (Baryshevsky, 2004; Capie et al., 2005). But gold has historically been more than just a safe haven. It's also played a vital role in the monetary system as real money. The demand for gold has recently surged as investors have turned to the precious metal to protect against global uncertainty and as a way to hedge against inflationary concerns. The metal's price is up a stunning 619 percent (2011) since its low in 1999, while the S\&P 500 index is down 16 percent. Therefore, the fluctuation of international gold price is crucial for the value of the Australian dollar. To get some insight into the trend between the two variables under study we plot daily gold prices and the AU dollar/US dollar exchange rate in Figure 1. In Figure 1, there is clear evidence of a substantial importance of gold prices for the course of the AU dollar/US dollar exchange rate. In other words, the surge in gold prices appears to be associated with the exchange rate. Our research will test empirically the validity of this hypothesis. 


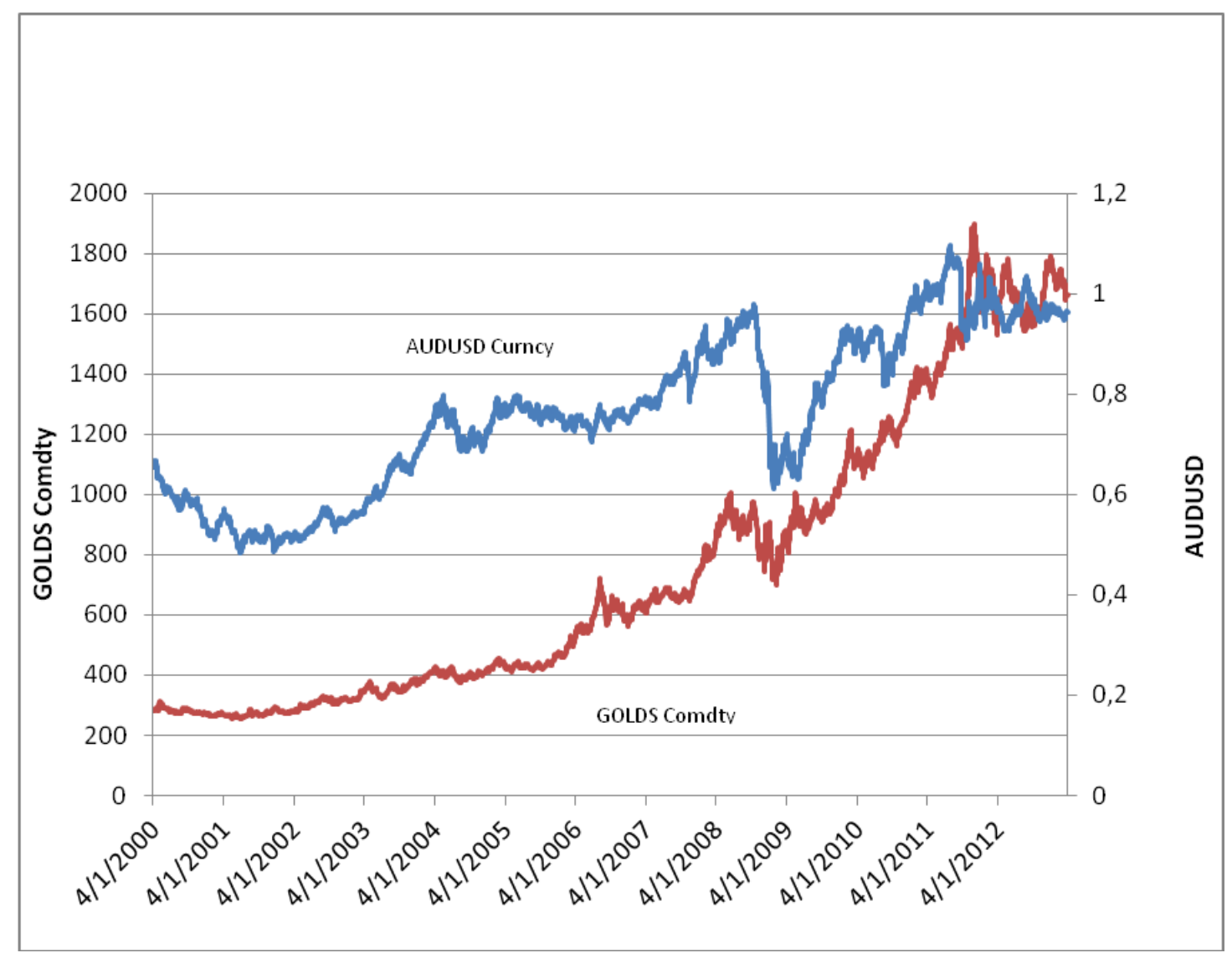

Fig. 1. Daily gold and the AUD/USD prices.

This paper contributes to the relevant literature by focusing on investigating, for the first time, the dynamic relationship between nominal and real exchange rate changes and gold prices in Australia. According to Chen and Rogoff (2003), the empirical results are expected to offer potential insight to the policymakers, on the grounds that: i) there is great concern in the literature about whether policymakers in small open economies should respond to exchange rate movements when setting monetary policy (Brischetto and Voss, 1999; Dungey and Pagan, 2000) and ii) foreign exchange traders, hedge funds managers and international portfolio managers could potentially benefit, in cases where trading among currencies requires the examination of the relationships between different markets to capitalize on the opportunity.

The paper is organized as follows. Section 2 comprises the empirical implementation of the study, including a description of the data and the econometric results, while Section 3 performs the forecasting exercise. Section 4 reports robustness empirical test results and, finally, section 5 summarizes the results and concludes. 


\section{Empirical analysis and results}

\subsection{Data}

Daily data on gold prices (GP) and the Australian dollar/US dollar exchange rate (AUD) were obtained from Bloomberg spanning the period 2000-2012. For the purposes of the empirical analysis, demeaned continuously compounding percentage returns of gold prices and the exchange rate are computed by taking the daily difference of the natural logarithms, subtracting the sample mean and multiplying by 100. Gold prices are US closing spot gold, published in the New York COMEX as Cash Gold Prices.

The empirical analysis will also be implemented with respect to the real exchange rate (RER). To this end, monthly data on domestic and US prices (proxied by CPI indices), obtained from Datastream, on the long-term real interest rates (proxied by the 10-year bond rates), also obtained from Datastream, and, on the terms of trade (TT), obtained from International Financial Statistics, were employed. Real interest rates were calculated as the difference between the nominal interest rates and actual inflation. Throughout the paper, lower-case letters, except for the case of longterm real interest rates, signify variables in natural logarithms, while the RATS software (Version 7.0) assisted the empirical analysis.

\subsection{Integration analysis}

We test for unit root non-stationarity by using the tests proposed by Dickey and Fuller (1981). In particular, the analysis is based on the augmented Dickey-Fuller unit root tests, the results of which are presented in Table 1. Using a 5 per cent significance level, those data clearly accept the hypothesis of a unit root for both series in levels. When first differences were used, unit root non-stationarity was rejected both cases.

However, the power of the statistical unit root test is of critical importance. Therefore, two modified Dickey-Fuller tests with good power are also applied. They are the DF-WS test, proposed by Park and Fuller (1995), which makes use of the WSLS estimator, which is more efficient then the OLS estimator in estimating 
autoregressive parameters and the DF-GLS test, proposed by Elliott et al. (1996), which analyzes the sequence of Neyman-Pearson tests of the null hypothesis of the presence of a unit root. The results are also reported in Table 1. They indicate that all the variables are integrated of order one.

\section{Table 1}

Unit root tests

\begin{tabular}{|c|c|c|c|c|}
\hline \multicolumn{5}{|c|}{ ADF Tests } \\
\hline \multirow{4}{*}{$\begin{array}{l}\text { gp } \\
\text { aud }\end{array}$} & \multirow{2}{*}{\multicolumn{2}{|c|}{$\begin{array}{c}\text { Levels } \\
\text { Without trend With trend }\end{array}$}} & \multirow{2}{*}{\multicolumn{2}{|c|}{$\begin{array}{c}\text { First differences } \\
\text { Without trend With trend }\end{array}$}} \\
\hline & & & & \\
\hline & $-1.34(6)$ & $-1.77(6)$ & $-6.63(5)^{*}$ & $-6.71(5)^{*}$ \\
\hline & $-1.21(6)$ & $-1.75(6)$ & $-7.53(5)^{*}$ & $-8.70(4) *$ \\
\hline$\overline{\text { rer }}$ & $-1.32(3)$ & $-1.76(3)$ & $-5.66(2)^{*}$ & $-6.18(1)^{*}$ \\
\hline $\mathrm{tt}$ & $-1.18(3)$ & $-1.46(4)$ & $-4.53(2)^{*}$ & $-5.39(2) *$ \\
\hline dri & $-4.58(2)^{*}$ & $-5.26(2)^{*}$ & & \\
\hline
\end{tabular}

\section{DF-WS Test}

Levels (trend)

$\begin{array}{ll}\text { gp } & -1.21(4) \\ \text { aud } & -1.29(5) \\ \text { rer } & -1.25(3) \\ \text { tt } & -1.16(3) \\ \text { dri } & -5.12(2)^{*}\end{array}$

First differences-trend

$-5.60(3)^{*}$

$-5.31(3)^{*}$

$-4.75(2)^{*}$

$-5.68(1)^{*}$

\section{DF-GLS}

$\begin{array}{lll}\text { gp } & -1.14(5) & -6.11(2)^{*} \\ \text { aud } & -1.23(5) & -5.25(3)^{*} \\ \text { rer } & -1.14(3) & -5.61(2)^{*} \\ \text { tt } & -1.48(2) & -5.32(1)^{*} \\ \text { dri } & -1.35(3) & -4.87(2)^{*}\end{array}$

Numbers in parentheses denote the optimal number of lags used in the augmentation of the test regression and were obtained through the Akaike criterion

* indicates that the unit root null hypothesis is rejected at the 5 per cent level.

2.3. Modelling mean processes for gold prices and the AU dollar/US dollar exchange rate

In this section, the analysis identifies both the gold prices and the AU dollar/US dollar exchange rate processes. A gold prices-AU dollar/US dollar 
exchange rate system consists of the following Error Correction (EC) model equations:

$$
\begin{gathered}
\Delta \mathrm{gp}_{\mathrm{t}}=\mathrm{a}_{10}+\sum_{\mathrm{i}=1}^{8} \mathrm{a}_{1 \mathrm{i}} \Delta \mathrm{gp}_{\mathrm{t}-\mathrm{i}}+\sum_{\mathrm{i}=1}^{8} \mathrm{a}_{2 \mathrm{i}} \Delta \mathrm{aud}_{\mathrm{t}-\mathrm{i}}+\mathrm{b}_{1} \mathrm{EC}_{\mathrm{t}-1}+\mathrm{u}_{1 \mathrm{t}} \\
\operatorname{aud}_{\mathrm{t}}=\mathrm{a}_{20}+\sum_{\mathrm{i}=1}^{8} \mathrm{a}_{3 \mathrm{i}} \Delta \mathrm{gp}_{\mathrm{t}-\mathrm{i}}+\sum_{\mathrm{i}=1}^{8} \mathrm{a}_{4 \mathrm{i}} \Delta \mathrm{aud}_{\mathrm{t}-\mathrm{i}}+\mathrm{b}_{1} \mathrm{EC}_{\mathrm{t}-1}+\mathrm{u}_{2 \mathrm{t}}
\end{gathered}
$$

with EC being the cointegration residuals, while $\mathrm{u}_{1 \mathrm{t}}$ and $\mathrm{u}_{2 \mathrm{t}}$ denote error terms. Finally, $\mathrm{a}_{10}$ and $\mathrm{a}_{20}$ are constants, whilst $\mathrm{a}_{\mathrm{is}}$ are the coefficients of explanatory variables. The optimal lag length, that is 8 , was chosen by minimizing the Bayesian information criterion (BIC) for lag lengths one to twenty four.

Next, Johansen and Juselius (1990) cointegration tests are performed. They reveal evidence in favor of cointegration between gold prices and the AU dollar/US dollar exchange rate. The cointegration results are reported in Table 2. Both the eigenvalue test statistic and the trace test statistic indicate that there is a single longrun relationship among the variables under study. Once the presence of a cointegrating relationship is established, an associated all-encompassing EC system, which describes the short-run dynamics, is also considered. This specification models the mean equations for gold prices and the AU dollar/US dollar exchange rate.

\section{Table 2}

Cointegration tests

\begin{tabular}{lccccc}
\hline Lags $=\mathbf{6}$ & & & & & \\
$\mathrm{r}$ & $\mathrm{n}-\mathrm{r}$ & $\mathrm{ml}$ & 95 per cent & $\mathrm{Tr}$ & 95 per cent \\
$\mathrm{r}=0$ & $\mathrm{r}=1$ & 60.5538 & 29.0000 & 65.6311 & 51.3500 \\
$\mathrm{r}<=1$ & $\mathrm{r}=2$ & 1.1877 & 10.4400 & 1.1877 & 10.4400
\end{tabular}

$\mathrm{r}$ is the number of cointegrating vectors, $\mathrm{n}-\mathrm{r}$ is the number of common trends, $\mathrm{ml}=$ maximum eigenvalue statistic, $\operatorname{Tr}=$ Trace statistic. The number of lags was determined through Likelihood Ratio tests, developed by Sims (1980).

Normalizing the cointegration vector on the nominal exchange rate, we obtain the following estimates:

$$
\begin{aligned}
\text { aud }= & 1.437-0.547 \mathrm{gp} \\
& (7.19)^{*}(-6.58)^{*}
\end{aligned}
$$


R-squared $=0.29 \quad \mathrm{LM}=1.25[0.41] \quad \mathrm{RESET}=1.19[0.43]$

Numbers in parentheses denote t-statistics, while an asterisk denotes significance at the $1 \%$ statistical level. LM and RESET are tests for serial correlation and model functional misspecification, respectively, while figures in brackets denote p-values. The coefficient on gold prices is correctly signed and statistically significant. It shows that a one percent increase in gold prices leads to an appreciation of the exchange rate by virtually 0.55 percent.

Table 3 reports the results from the estimations of the EC system. Looking at the models' overall performance as reported by the diagnostics, the estimated equations satisfy certain econometric criteria, namely, absence of serial correlation (LM test) and absence of model functional misspecification (RESET test).

\section{Table 3}

Error correction model estimates

\begin{tabular}{lll}
\hline Coefficient & Gold Prices & AU dollar/US dollar exchange rate \\
\hline $\mathrm{a}_{10}$ & $0.034(1.36)$ & \\
$\mathrm{a}_{11}$ & $0.295(7.24)^{*}$ & \\
$\mathrm{a}_{12}$ & $0.152(5.37)^{*}$ & \\
$\mathrm{a}_{13}$ & $0.105(4.97)^{*}$ & \\
$\mathrm{a}_{14}$ & $0.124(4.82)^{*}$ & \\
$\mathrm{a}_{15}$ & $0.085(4.69)^{*}$ & \\
$\mathrm{a}_{21}$ & $0.150(8.16)^{*}$ & \\
$\mathrm{a}_{22}$ & $0.119(5.24)^{*}$ & \\
$\mathrm{a}_{23}$ & $0.123(5.07)^{*}$ & \\
$\mathrm{a}_{24}$ & $0.106(4.81)^{*}$ & \\
$\mathrm{a}_{25}$ & $0.033(4.36)^{*}$ & \\
$\mathrm{~b}_{1}$ & $-0.142(-5.93)^{*}$ & \\
& & \\
$\mathrm{a}_{20}$ & & $-0.048(1.14)$ \\
$\mathrm{a}_{31}$ & & $-0.141(-4.47)^{*}$ \\
$\mathrm{a}_{32}$ & & $-0.113(-4.71)^{*}$ \\
$\mathrm{a}_{33}$ & & $-0.127(-4.24)^{*}$ \\
$\mathrm{a}_{34}$ & & $-0.109(-4.72)^{*}$ \\
$\mathrm{a}_{35}$ & & $0.285(5.53)^{*}$ \\
$\mathrm{a}_{41}$ & & $0.236(5.19)^{*}$ \\
$\mathrm{a}_{42}$ & & $0.126(4.47)^{*}$ \\
$\mathrm{a}_{43}$ & & $0.085(4.18)^{*}$ \\
$\mathrm{a}_{44}$ & & $0.071(4.48)^{*}$ \\
$\mathrm{a}_{45}$ & & $-0.275(-5.82)^{*}$ \\
$\mathrm{~b}_{2}$ & &
\end{tabular}


Diagnostic statistics

$\begin{array}{lll}\mathrm{R}^{2} & 0.28 & 0.25 \\ \mathrm{LM} & 1.84[0.30] & 2.05[0.37] \\ \text { RESET } & 1.23[0.28] & 1.53[0.53]\end{array}$

Figures in parentheses denote t-statistic values, while those in brackets p-values. LM is a serial correlation test and RESET is a functional misspecification test.

* denotes significance at 5 per cent

\section{Gold prices and the nominal Australian dollar/US dollar exchange rate: a forecasting exercise}

This section performs a forecasting exercise in order to evaluate whether changes in gold prices contain information about future changes in the Australian dollar/US dollar exchange rate. Notice that in terms of the EC model, the lagged values of gold prices are used for prediction. We estimate the parameters from 2000 to 2009 and generate sequences of ahead pseudo out-of-sample forecasts conditional on the lagged values of gold prices. The observation corresponding to the first day in 2010 is added to the estimation sample, the models are re-estimated and the procedure is iterated until no usable out-of-sample observations are left. Then, we compare the gold price-based forecasts with those of the random walk by using two types of statistics: root mean squared errors (RMSE) and the U-Theil ratio, which compares the RMSE for each model against the best model chosen as a benchmark. The results are reported in Table 4.

\section{Table 4}

Forecasting results: the nominal exchange rate

\begin{tabular}{llll}
\hline \multicolumn{2}{c}{ RW model } & \multicolumn{2}{c}{ EC model } \\
RMSE & U-Theil & RMSE & U-Theil \\
\hline 0.071 & 0.514 & 0.048 & 0.439 \\
0.242 & 0.608 & 0.194 & 0.478 \\
0.303 & 0.613 & 0.231 & 0.510 \\
0.329 & 0.638 & 0.254 & 0.549 \\
0.347 & 0.651 & 0.311 & 0.578 \\
0.363 & 0.663 & 0.323 & 0.627 \\
0.386 & 0.725 & 0.336 & 0.648
\end{tabular}


The results indicate that the EC model that includes gold prices performs better than the benchmark random walk model. In other words, the results speak clearly for the inclusion of information on gold prices when forecasting the Australian dollar/US dollar exchange rate, while the results remain robust across forecasting horizons.

\section{Robustness tests: the real exchange rate}

In the relevant literature, the fundamental approach to the determination and estimation of the equilibrium real exchange rate has been criticized on the grounds that attempts to model long-run movements in real exchange rates have generally generated mixed results. In particular, Edison and Melick (1999) fail to find the presence of a long-run relationship between real exchange rates and real interest rate differentials, while Cashin et al. (2004) argue that the PPP hypothesis provides empirical results about a weak long-run real exchange rate model. The least controversial studies display that there is a relation between the real exchange rate and a number of macroeconomic variables (Edwards, 1989; Smith, 1999; Chen and Rogoff, 2003). Chen and Rogoff (2003) recognize that if researchers could find a source of real shocks that is sufficiently volatile, they could resolve the puzzle of mixed results. The above real factors play a significant role in the determination of the real exchange rate through certain mechanisms, such as the Balassa-Samuelson effect (Choudhri and Khan, 2004).

More importantly, for the case of an exporting country, the role of terms of trade is exceptionally high. In this case, real exchange rate policies should be directed to align the real exchange rate with its fundamental determinants and, in our case, with changes in gold prices. Chen and Rogoff (2003) focus on three 'commodity currencies' issued by large advanced countries, Australia, Canada and New Zealand. They find that commodity prices have a strong effect on their real exchange rates, especially in Australia and New Zealand. Cashin et al. (2004) find that commodity terms of trade affect the real exchange rate, while Ricci et al. (2008) estimate a panel cointegration relationship between fundamentals and real exchange rates in a sample of 48 countries. 
The analysis identifies the appropriate AU dollar/US dollar real exchange rate process and is based on a version of the model estimated by Gruen and Wilkinson (1994). In particular, for a small, commodity-exporting country like Australia, changes in the terms of trade reflect changes in international commodity prices and have a direct impact on net exports and hence on the current account of the balance of payments. An unexpected deterioration in the terms of trade worsens the current account deficit. The unexpected increase in the current account deficit leads to a real depreciation in the exchange rate.

Moreover, an additional role is also given to interest rate differentials (ri) in the relationship under examination. Therefore, we employ long-term real interest rate differentials as an indicator of the anticipated stance of Australian monetary policy relative to that in the US. An increase in the long-term real interest rate differentials favoring Australia would indicate a relative restrictive monetary policy in Australia. We should expect this to lead, other things equal, to a real appreciation of the AU dollar.

After identifying the presence or not of unit roots in the new variables (Table 1), the AU dollar/US dollar real exchange rate is well described by the following Vector Autoregressive (VAR) model equation (the absence of a uniform unit root pattern prevents the presence of cointegration):

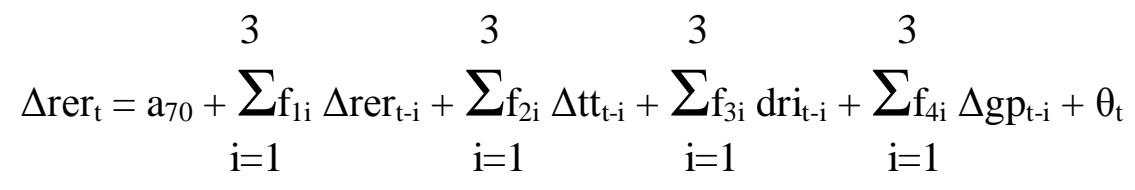

with $\theta_{\mathrm{t}}$ being the error term. Next, the $\Delta \mathrm{gp}$ and $\Delta$ rer equations form a 4-variable equation system, i.e. $\Delta \mathrm{rer}, \Delta \mathrm{gp}, \Delta \mathrm{tt}$ and dri, and the results are reported in Table 5 (we focus only on equations $\Delta \mathrm{gp}$ and $\Delta \mathrm{rer}$, while the remaining results are available upon request). Here, gold prices have been deflated through the Australian CPI index. Changes in real interest rates lead to changes in the demand for or the supply of commodities either through changing the incentive for extraction today rather than tomorrow or through changing a firm's desire to carry inventories or, finally, by encouraging speculators to shift out or into of commodity contracts and into bonds. We may call it part of the 'carry trade'.

Once again, only the statistical significant variables are reported. Looking at the models' overall performance, as reported by the diagnostics, the estimated 
equations satisfy certain econometric criteria, namely, absence of serial correlation (LM test) and absence of functional misspecification (RESET test).

Table 5

VAR model estimates

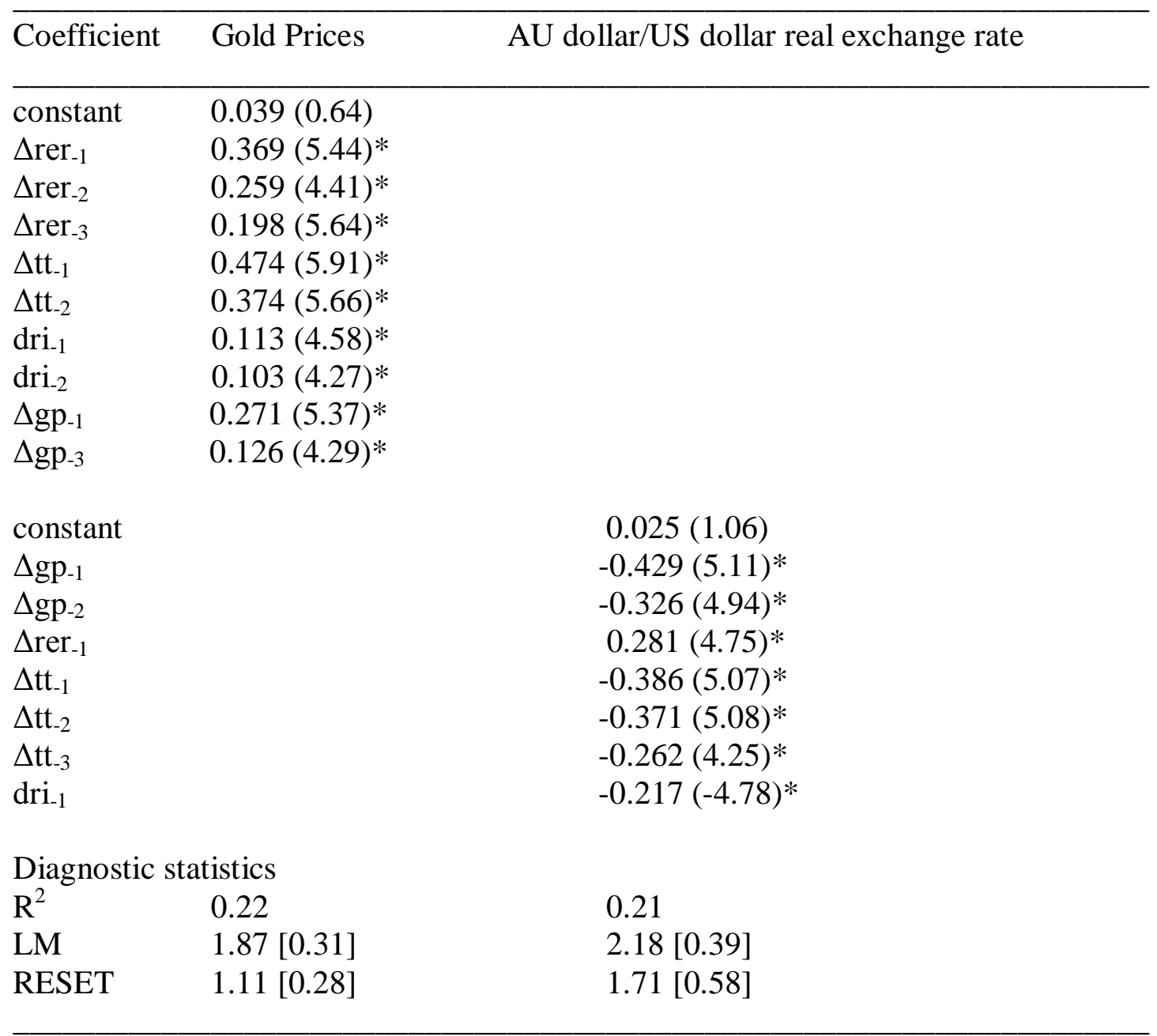

Similar to Table 3.

The above results denote that real shocks determine the behavior of the real exchange rate in the short-run, implying that a commodity exporting country like Australia can have either a flexible nominal exchange rate regime (which is the case for Australia), or facilitating slow changes of relative inflation or price and wage flexibility, or, finally, the maintenance of a nominal exchange rate peg.

Next, we also performed the forecasting exercise using the real exchange rate EC model and monthly forecasts. The results are reported in Table 6 and they reinforce those found in the nominal exchange rate case above. 
Table 6

Forecasting results: the real exchange rate

\begin{tabular}{llll}
\hline \multicolumn{2}{c}{ RW model } & \multicolumn{2}{c}{ EC model } \\
RMSE & U-Theil & RMSE & U-Theil \\
& & & \\
\hline 0.074 & 0.608 & 0.054 & 0.470 \\
0.227 & 0.636 & 0.217 & 0.485 \\
0.263 & 0.671 & 0.252 & 0.526 \\
0.306 & 0.694 & 0.274 & 0.548 \\
0.336 & 0.729 & 0.296 & 0.581 \\
0.424 & 0.746 & 0.338 & 0.606 \\
\hline
\end{tabular}

Once again, the empirical findings offer extra evidence concerning the fact that gold prices contain information about future developments of the Australian dollar/US dollar exchange rate.

\section{Conclusions}

This paper provided evidence that gold prices do matter in forecasting the Australian dollar/US dollar exchange rate, with daily and monthly data, for nominal and real exchange rates, respectively. The results showed that gold prices information improves AU dollar/US dollar exchange rate forecasts significantly vis-à-vis the random walk behavior.

These empirical findings are extremely important, in terms of information availability, for gold exporters, monetary policymakers, hedge funds managers and international portfolio managers. Nevertheless, our results do not exclude that other channels may also be at work, such as demand shifts owing to monetary policy and asset or currency markets.

Our results could have potential policy implications: given the vulnerability of gold prices to monetary shocks (Frankel, 2008; Taylor, 2009), should monetary policy rules explicitly include gold prices volatility? To what extent is stable gold prices a prerequisite for stable exchange rates, e.g. for a stable US or an AU dollar? Which effect would a hard landing scenario of gold prices have on the exchange rate under study? 
Future research efforts could proceed in certain directions. For instance, a future empirical effort on a panel basis, i.e. with more countries characterized as gold exporters, could give a better perspective on the results that incorporate (panel) cointegration and (panel) error correction. In addition, future research should concentrate on exploring non-linearity and asymmetries in the relevant relation. Finally, making an explicit distinction between supply and demand shocks may also shed a light on the nature of the relationship (Kilian, 2009).

\section{Acknowledgements}

The author wishes to thank both a referee and the Editor of this journal for their valuable comments and suggestions that improved the quality of the paper. Needless to say, the usual disclaimer applies.

\section{References}

Baryshevsky, D.V. (2004). The Interrelation of the Long-Term Gold Yield with the

Yields of Another Asset Classes. Working Paper found at: http://ssrn.com/abstract $=652441$.

Baur, D.G. \& Lucey, B.M. (2007). Is Gold a Hedge or a Safe Haven? An Analysis of Stocks, Bonds and Gold. The Financial Review, 45, 217-229.

Beckmann, J. \& Czudaj, R. (2013, forthcoming). Oil Prices and Effective Dollar Exchange Rates. International Review of Economics and Finance, http://dx.doi.org/10.1016/j.iref.2012.12.002.

Blundell-Wignall, A., Fahrer, J. \& Heath, A. (1993). Major Influences on the Australian Dollar Exchange Rate. In Adrian Blundell-Wignall (ed.), The Exchange Rate, International Trade and the Balance of Payments, Sydney: Reserve Bank of Australia.

Blundell-Wignall, A. \& Gregory, R.G. (1990). Exchange Rate Policy in Advanced Commodity-Exporting Countries: The Case of Australia and New Zealand. Working Paper, No. 83/1990, Paris: OECD Department of Economics and Statistics. 
Brischetto, A. \& Voss, G. (1999). A Structural Vector Autoregressive Model of Monetary Policy in Australia. Reserve Bank of Australia Discussion Paper, No. 1999-11.

Capie, F., Mills, T.C. \& Wood, G. (2005). Gold as a Hedge Against the Dollar. Journal of International Financial Markets, Institutions and Money, 15, 343352.

Cashin, P., Cespedes, L.F. \& Sahay, R. (2004). Commodity Currencies and the Real Exchange Rate. Journal of Development Economics, 75, 239-268.

Chen, S.S. (2004). Real Exchange Rate Fluctuations and Monetary Shocks: A Revisit. International Journal of Finance and Economics 9, 25-32.

Chen, Y.C. \& Rogoff, K. (2003). Commodity Currencies. Journal of International Economics, 60, 133-160.

Chen, Y.C., Rogoff, K. \& Rossi, B. (2010). Can Exchange Rates Forecast Commodity Prices? Quarterly Journal of Economics, 125, 1145-1194.

Choudhri, T. \& Khan, M.S. (2004). Real Exchange Rates in Developing Countries: Are Balassa-Samuelson Effects Present? Working Paper, No. 04/188, Washington, International Monetary Fund.

Dickey, D.A. \& Fuller, W.A. (1981). Likelihood Ratio Statistics for Autoregressive Time Series With a Unit Root. Econometrica, 49, 1057-1072.

Dungey, M. \& Pagan, D.R. (2000). A Structural VAR Model of the Australian Economy. Economic Record, 76, 321-342.

Edison, H. \& Melick, W.R. (1999). Alternative Approaches to Real Exchange Rates and Real Interest Rates: Three Up and Three Down. International Journal of Finance and Economics, 4, 93-111.

Edwards, S. (1989). Exchange Rate Misalignment in Developing Countries. World Bank Research Observer, 4, 3-21.

Elliot, G., Rothenmberg, T.J. \& Stock, J.H. (1996). Efficient Tests for an Autoregressive Unit Root. Econometrica, 64, 813-836.

Engel, C., Mark, N. \& West, K.D. (2007). Exchange Rate Models are not as Bad as you Think. In NBER Macroeconomics Annual, D. Acemoglu, K. S. Rogoff \& M. Woodford (Eds.), Cambridge, MA: MIT Press. 
Ewing, B.T. and Malik, F. (2013). Volatility Transmission Between Gold and Oil Futures Under Structural Breaks. International Review of Economics and Finance, 25, 113-121.

Frankel, J.A. (2008). The Effect of Monetary Policy on Real Commodity Prices. In John Campbell (Ed.), Asset Prices andMonetary Policy, University Of Chicago Press, 291-327.

Frankel, J.A. \& Rose, A.K. (1995). A Panel Project on Purchasing Power Parity: Mean Reversion Within and Between Countries. Journal of International Economics, 40, 209-224.

Gruen, D.W. R. \& Wilkinson, J. (1994). Australia's Real Exchange Rate: Is It Explained by the Terms of Trade or by Real Interest Rate Differentials? Economic Record, 70, 204-219.

Hammoudeh, S.M., Yuan, Y., McAleer, M. \& Thompson, M.A. (2010). Precious Metals-Exchange Rate Volatility Transmissions and Hedging Strategies. International Review of Economics and Finance, 19, 633-647.

Isard, P. (2007). Equilibrium Exchange Rates: Assessment Methodologies. IMF Working Paper, No. 07/296, Washington: International Monetary Fund.

Johansen, S. \& Juselius, K. (1990). Maximum Likelihood Estimation and Inference on Cointegration-With Applications to the Demand for Money. Oxford Bulletin of Economics and Statistics, 52, 169-210.

Kilian, L. (2009). Not All Oil Price Shocks are Alike: Disentangling Demand and Supply Shocks in the Crude Oil Market. American Economic Review, 99, 1053-1069.

Meese, R. \& Rogoff, K.S. (1983). Exchange Rate Models of the Seventies: Do they Fit Out of Sample? Journal of International Economics, 14, 3-24.

Molodtsova, T. \& Papell, D.H. (2009). Out-of-Sample Exchange Rate Predictability With Taylor Rule Fundamentals. Journal of International Economics, 77, 167180.

Obstfeld, M. \& Rogoff, K.S. (1996). Foundations of International Macroeconomics, Cambridge, MA: MIT Press.

Park, H.J. \& Fuller, W.A. (1995). Alternative Estimators and Unit Root Tests for the Autoregressive Process. Journal of Time Series Analysis, 16, 415-429. 
Ricci, L.A., Milesi-Ferretti, G.M. \& Lee, J. (2008). Real Exchange Rates and Fundamentals: A Cross-Country Perspective. IMF Working Paper, No. 08/013, Washington: International Monetary Fund.

Sercu, P. \& Uppal, R. (1999). Exchange Rate Volatility and International Trade: A General-Equilibrium Analysis. European Economic Review 47, 429-441.

Sercu, P. and Uppal, R. (1995). Exchange Rate Determination. International Financial Markets and the Firm. London: Chapman and Hall.

Sims, C. A. (1980). Macroeconomics and Reality. Econometrica, 48, 1-48.

Smith, C.E. (1999). Exchange Rate Variation, Commodity Price Variation and the Implications for International Trade. Journal of International Money and Finance, 18, 471-491.

Taylor, J.B. (2009). The Financial Crisis and the Policy Responses: An Empirical Analysis of What Went Wrong. NBER Working Paper, No. 14631.

Viney, C. (2000). Financial Institutions and Markets. The McGraw Hill Companies.

Wang, J. \& Wu, J. (2012). The Taylor Rule and Forecast Intervals for Exchange Rates. Journal of Money, Credit and Banking, 44, 103-144. 